\title{
Growth and Yield of Three Boreal Tree Species
}

\author{
Petri P. Kärenlampi* \\ Lehtoi Research, Finland \\ petri.karenlampi@professori.fi
}

*Author to whom correspondence should be addressed.

\begin{abstract}
Growth and yield of boreal tree species are discussed. A growth model is applied, along with verified yield models of sawlogs and veneer logs. Using the normal forest-principle, thinning schedules and rotation ages maximizing the estate-level capital return rate are clarified. Regeneration expenses are amortized at the end of any rotation. Consequently, capitalizations are greater and rotations longer than in recent studies. The capital return rate is a weak function of initial stem count but differs by tree species. The initial stem count strongly contributes to biomass stored in trees. The most promising way of increasing the capital return rate is the reduction of regeneration expenses. Thinnings are triggered by stand volumes of at least 200 $\mathrm{m}^{3} /$ ha. The average commercial trunk volume of trees removed in thinnings always exceeds 200 liters. Risk aversion theory proposes short rotations and low stem count in seedling planting unless carbon storage compensation exists.
\end{abstract}

Keywords: Pinus silvestris; Picea abies; Betula pendula; Betula pubescens

\section{Introduction}

Boreal forests constitute a significant carbon sink, and a significant source of income for local populations, directly and indirectly. Forest do have conservation values and play a role in maintaining biological diversity in ecosystems. Not all incentives necessarily unify. Increased harvesting is at least partially contradictory to carbon sink but may substitute fossil materials 
$[1,2,3,4,5]$. A high production rate, along with high capitalization, may be favorable for society economics, whereas lower capitalization may favor private equity capital return rate $[6,7,8,9]$.

As the preferences of the society do not necessarily unify with the preferences of a private forest owner, compensations systems for complying with society goals have been proposed $[10,11]$. The necessary level of compensation has been recently discussed $[9,12,13,14]$.

From the viewpoint of generic instructions, or policy actions, it might be beneficial to reduce the variety of estate states by adopting some kind of unifying boundary condition. A tempting candidate is the normal forest principle [15]. This principle simply refers to postulating that stand ages are evenly distributed and stand characteristics are uniquely determined by stand age. Such a postulation, even if often departing from reality, simplifies many treatments, producing idealized systems that are stationary in time. Application of the normal forest principle allows the determination of an optimal rotation age, as well as financially suitable expected values of estate characteristics.

Recent treatments, based on the normal forest principle, have been based on observations collected from spruce-dominated forests of age 30-45 years, where first thinning has been due $[9,13,14]$. A few such stands have been used as normal stands, describing a few normal forests. Stand development until observation has been approximated in terms of empirical models, and further development of any normal stand in terms of a growth model $[16,7,8]$.

The regime of this study is fertile boreal forest on mineral soil. The growth model applied has been calibrated in Norway, and previously applied as such in Eastern Finland [16,7,8]. When necessary, prices and expenses are taken from sources relevant to the Southern half of Finland, applicable at the time of writing (2021).

This paper intends to clarify a few issues related to the recent investigations. Firstly, since observations of never-thinned stands of age 30-45 years have been used as a starting point, it has not been possible to determine whether the stands should have been thinned earlier. Secondly, only spruce (Picea Abies) forest has been considered. Scots pine and birch species also are important in the area. 
To clarify the feasible timing of thinnings, we will now apply the growth model, not for stands of age 30 to 45 years, but as early as it is applicable. In other words, the growth model is applied to young stands where breast-height diameters are 6-11 centimeters, which is achieved in 1520 years, depending on tree species $[17,18,19,20,21]$. Such an approach, however, requires the investigation of a variety of alternative stem counts retained in young stand cleaning.

A third significant difference to the recent investigations $[9,13,14]$ is the amortization of regeneration expenses. As the treatment was based on observations at age 30-45 years, regeneration was assumed to result as the young stand where the first harvesting was due. In other words, regeneration expenses were offset by the young stand growth until the time of observation. Here, on the contrary, we capitalize the regeneration expenses at the time of regeneration and deduct the expenses first at the end of any rotation.

First, the applied growth and yield models are presented. Financial and computational methods are presented. Then, results are reported, for three different tree species, as well as for three different initial stand stem counts. Finally, the results are discussed, and conclusions regarding their robustness are given.

\section{Materials and Methods}

\subsection{Growth model}

For prognostication of the development of any normal stand, some kind of a growth model is needed. The growth model of Bollandsås et al. [16,7,8] is adopted, discussing not only growth but also mortality and recruitment. The original growth model $[16,7,8]$ discussed $50 \mathrm{~mm}$ breastheight diameter classes within a temporal resolution of five years. Any diameter class was represented by its central tree, and the process of growth was described in terms of the probability of any tree to transfer to the next diameter class $[16,7,8]$. The underlying idea of the description of growth is that any tree either remains in the same diameter class or transfers to the next diameter class within the five-year time interval. This underlying idea naturally greatly simplifies computation.

Recent investigations have demonstrated a need for a greater than $50 \mathrm{~mm}$ resolution in the tree size description $[13,14]$. It is not too complicated to modify the growth model from the size 
resolution of $50 \mathrm{~mm}$ to $25 \mathrm{~mm}$. To retain the underlying principle of the growth model, this requires a corresponding change in the temporal resolution, from 5-year time steps to 30 months. The simultaneous change in the time and size resolutions retains the probability of any tree to transfer to the next diameter class. Recruitment and mortality are affected by time resolution only. Correspondingly, the recruitment and mortality values become scaled along with the time step by a factor of $1 / 2$. For a base case, a site fertility index of 17 is used in this study. The index number corresponds to the dominant height at the breast-height age of 40 years [16].

\subsection{Yield model}

For any 25-mm diameter class of trees, two assortments, pulpwood and sawlogs (or plywood $\operatorname{logs}$ ), are prospectively produced. A model for the yield of such assortments has recently been empirically verified [22]. The yield model based on inventory data [23] is of however wider applicability than any single empirical dataset. Consequently, the yield of assortments is approximated as follows.

First, the trunk taper curves of Laasasenaho [24] are applied. The taper curves need to be calibrated for trunk aspect ratio. For any breast-height diameter, the empirical dataset reported in [22] is used to determine an applicable aspect ratio. Then, any taper curve is used to determine a geometric estimate for the volumes of sawlogs/plywood logs on the one hand, and pulpwood on the other. Such volumes, however, are not realistic, due to quality variations $[23,13,14,22]$. The sawlog/plywood log volume is corrected using the correction factors by Mehtätalo [23]. The correction factors require trunk age, in addition to trunk diameter. A typical age for any diameter is introduced as a nonproportional linear model for any tree species, established based on literature data $[17,18,19,20,21]$.

The stumpage value of any assortment is determined in terms of roadside price, deduced by harvesting expense. We use the roadside prices recently applied by Parkatti et al. [25,26], with one exception. The price premium of spruce pulpwood, in comparison to pine and birch pulpwood, has recently deteriorated due to industry restructuring and is not applied here. Further, the sawlog and plywood log roadside prices given by Parkatti et al. as such are used only in thinnigs. In the case of clearcutting, a 15\% premium is applied for the roadside price of sawlogs and plywood logs, following with regional tradition. 
We further use the same harvest-expense function as Parkatti et al. [26], based on a productivity study of Nurminen et al. [27]. Clearcutting expenses are lower than thinning harvesting costs, and expenses vary by tree species. A fixed entry expense of $200 \mathrm{Eur} / \mathrm{ha}$ is applied at the instant of harvesting. The justification is an eventual need for pre-harvest cleaning.

\subsection{Financial treatment}

To determine a momentary capital return rate, we need to discuss the financial resources occupied $[7,12,28,9]$. This is done in terms of a financial potential function, defined in terms of capitalization per unit area $K$. The momentary capital return rate becomes

$$
r(t)=\frac{d \kappa}{K(t) d t}
$$

where $\kappa$ in the numerator considers value growth, operative expenses, interests and amortizations, but neglects investments and withdrawals. In other words, it is the change of capitalization on an economic profit/loss basis. $K$ in the denominator gives capitalization on a balance sheet basis, being directly affected by any investment or withdrawal. It is worth noting that timber sales do not enter the numerator of Equation (1): selling trees at market price levels does not change the amount of wealth, it only converts wealth from trees into the form of cash. However, harvesting naturally changes capitalization appearing in the denominator of Equation (1). Harvesting also likely changes the change rate of capitalization occurring after the harvest. Equation (1) gives a momentary capital return rate, not necessarily sufficient for management considerations. By definition, the expected value of capitalization per unit area is

$$
\langle K\rangle=\int_{-\infty}^{\infty} p(K) K d K
$$

where $p(K)$ is the probability density function of capitalization $K$. By change of variables we get

$$
\langle K\rangle=\int_{0}^{\tau} p(K) K \frac{d K}{d a} d a=\int_{0}^{\tau} p(a) K(a) d a
$$


where $a$ is stand age (or time elapsed since latest regeneration harvesting), and $\tau$ is rotation age. The expected value of the change rate of capitalization is

$\left\langle\frac{d \kappa}{d t}\right\rangle=\int_{0}^{\tau} p(a) \frac{d \kappa(a)}{d t} d a$

Correspondingly, the expected momentary rate of relative capital return is

$$
\langle r(t)\rangle=\frac{\left\langle\frac{d \kappa}{d t}\right\rangle}{\langle K\rangle}=\frac{\int_{0}^{\tau} p(a) \frac{d \kappa(a, t)}{d t} d a}{\int_{0}^{\tau} p(a) K(a, t) d a}=\frac{\int_{0}^{\tau} p(a) K(a, t) r(a, t) d a}{\int_{0}^{\tau} p(a) K(a, t) d a}
$$

We find from Equation (5) that the expected value of capital return rate within an estate generally evolves in time as the probability density of stand ages evolves. However, Equation (5) can be simplified to be independent of time by adopting the normal forest principle, where stand age probability density is constant [15]. Besides, the constancy of the expected value of capital return rate in time requires that prices and expenses do not evolve in real terms. Then, the expected value of the capital return rate becomes

$$
\langle r\rangle=\frac{\int_{0}^{\tau} \frac{d \kappa(a)}{d t} d a}{\int_{0}^{\tau} K(a) d a}=\frac{\int_{0}^{\tau} K(a) r(a) d a}{\int_{0}^{\tau} K(a) d a}
$$

It has been recently shown that Equation (6) corresponds to the ratio of the partition functions of the change rate of capitalization and capitalization itself [29]. It also has been recently shown that the maximization of the net present value of future revenues may result in financially devastating consequences [30]. Momentary capital return rate as given in Equation (1) was introduced in 1860 [28]; an expected value was mentioned in 1967 [31,32], however applications have been introduced only recently $[7,8,29,30,9,13,14]$.

\subsection{Computational procedures}

As mentioned in the Introduction, the growth model is applied as early as it is applicable. In other words, the growth model is applied to young stands where breast-height diameters are 611 centimeters, which is achieved in 15-20 years of age, depending on tree species 
$[17,18,19,20,21]$. Such an approach, however, requires the investigation of a variety of alternative stem counts retained in young stand cleaning. We have chosen to investigate stem counts 1200, 1800, and 2400/ha.

As the growth model is not applicable to young seedlings, the stand development until breastheight diameters 6-11 centimeters must be approximated some other way. For this period, an exponential volume growth, as well as an exponential value increment is assumed. Further on, volumetric growth is produced using the growth model $[16,7,8]$, and value growth also using the yield model $[24,23,13,14,22]$.

The two smallest $25 \mathrm{~mm}$ breast-height diameter classes used are centered at 75 and $100 \mathrm{~mm}$. The applied growth model yields a volumetric growth rate for any trunk in any of these two diameter classes, and correspondingly to a volumetric growth rate per hectare. The same applies to value growth and capital return rate. On the other hand, an expected value of growth and capital return rate for a period beginning from regeneration are produced as the exponential approximations. It is required that the growth and return computed using the growth model for the first 30-month period where the model is applicable is greater than the expected value for the history since then. This restricts large stem counts mainly to the smaller class of breastheight diameter.

As mentioned in the Introduction, regeneration expenses are capitalized at the time of regeneration and deducted at the end of any rotation. The same applies to young stand cleaning expenses. Bare land value is always capitalized and never deducted. All expenses are discussed in terms of prices presently (2021) valid in Eastern Finland, without considering any timeevolution of expenses. Correspondingly, all financial expressions are in real, instead of nominal basis. Regeneration expenses are taken as 1250, 1450, and 1650 Euros per hectare for the stem counts 1200, 1800, and 2400/ha, respectively. These expenses include some excavator resources for partial stand drainage and minor road improvement. Young stand cleaning expense is always taken as $650 \mathrm{Eur} / \mathrm{ha}$, assumed to occur 10 years after regeneration.

After the establishment of any young stand with known stem count, the development of the stand is computed using the growth model, with 30-month time steps. Simultaneously, capital return rate according to Eq. (1) and accumulated expected value of capital return rate according to Eq. (6) are computed. The possibility for clearcutting is investigated at five-year intervals, 
using clearcutting prices and expenses. The maximum value of Eq. (6) indicates the economically optimal rotation age in the absence of any commercial thinning.

Then, eventual thinnings are introduced. Proportional thinnings are attempted, as well as thinnings from above. In the latter, the cutting diameter limit yielding the maximum of Eq. (6) is found. In the case of the first thinning, $20 \%$ of trees are removed regardless of size, due to the establishment of striproads. A suitable timing for the first thinning is found by maximizing Eq. (6).

If the introduction of one thinning increases the maximum value of Eq. (6), another thinning is attempted. The timing of the first thinning may have to change, to maximize Eq. (6), as well as the intensity of the first thinning. If an iterative search of the parameters of the two thinnings increases the maximal value of Eq. (6), in comparison to one thinning only, a third thinning is attempted.

\section{Results}

Fig. 1 shows the accumulated expected value of capital return rate for three tree species and three initial stem counts, as a function of rotation age. The achievable capital return rate is not sensitive to the initial stem count. There may be one, two, or three thinnings, depending on tree species and initial stem count. Proportional thinning is not feasible. Only thinning from above is better than no thinning. All thinnings from above are heavy thinnings where trees larger than $188 \mathrm{~mm}$ diameter are removed, in some cases all trees larger than $163 \mathrm{~mm}$, or $213 \mathrm{~mm}$.

The optimal rotation ages for pine stands are 66, 71 and 66 years for initial stem counts 1200, 1800, and 2400/ha, respectively. The corresponding expected annualized capital return rates are $3.55 \%, 3.60 \%$, and $3.65 \%$. The thinnings happen at age 46, (41 and 51) and (41 and 51) years.

There are two thinnings for spruce stands of lowest initial density, and three for the two higher. The optimal rotation age is 89 years for all initial for stem counts, and the corresponding maximal capital return rates 4.08\%/a, 4.30\%/a, and 4.45\%/a, for stem counts 1200, 1800, and 2400/ha. However, the capital return rates would be only slightly lower if clearcutting would 
happen after the first thinning, at age 64, 64, and 59 years. The capital return rates would be 4.01\%/a, 4.26\%/a, and 4.21\%/a. In the case of the initial stem count 1800/ha, this would require neglecting the second thinning. The first thinnings happen at age 44 years in all cases, and the second at 64, 54, and 59 years. For the two highest initial stem counts, the third thinning is designed for the age of 64 and 74 years. If there would be clearcutting instead of the last thinning, the expected value of capital return rate would become 4.15\%/a and 4.36\%/a.

Birch stands require only one thinning. The optimal rotation age is 99 years for the lowest initial stem count of 1200/ha, 94 years for 1800/ha and 2400/ha. The capital return rates are $1.99 \% / a, 1.98 \% / a$, and $2.00 \% / a$. The only thinning happens at age 59 years.

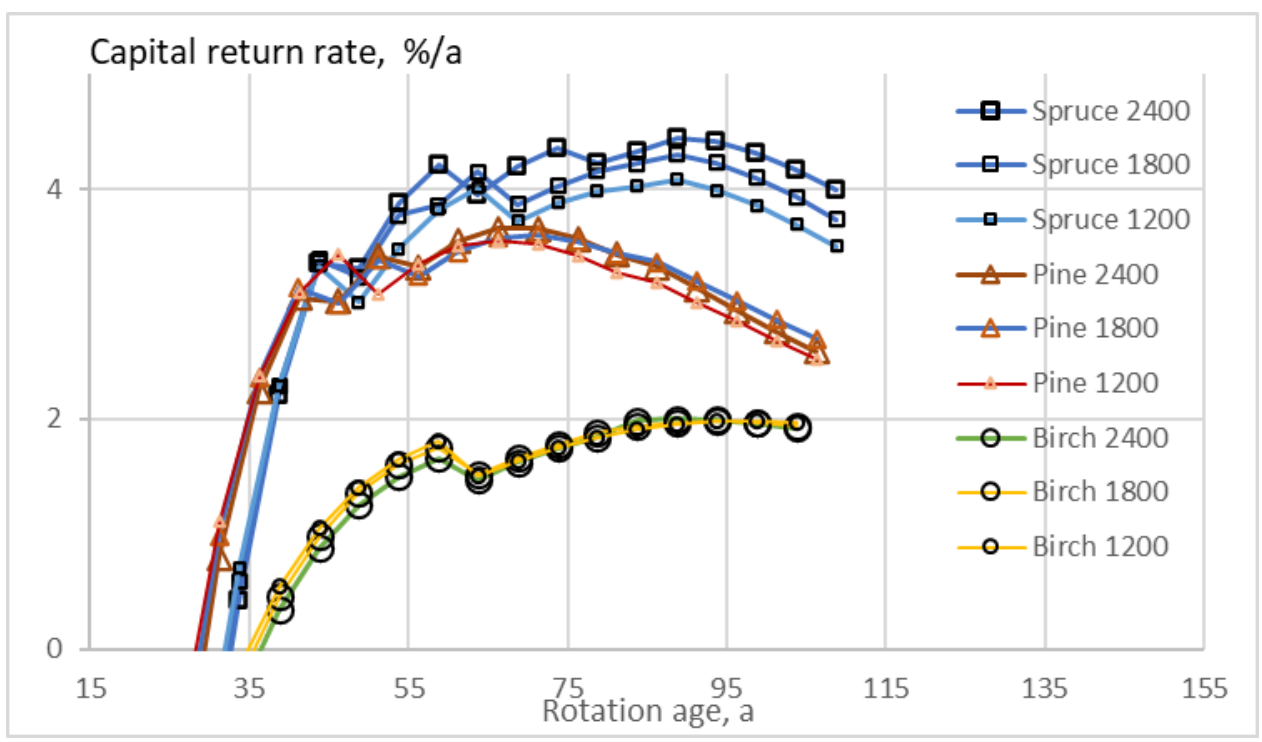

Fig. 1. Accumulated expected value of capital return rate for three tree species and three initial stem counts, as a function of rotation age.

Fig. 2 shows that the stem counts change not only by thinning but evolve due to the mortality and recruitment. The stem count of pine stands is monotonically reduced as mortality exceeds recruitment, except at stem counts below 1000/ha. The stem counts of spruce and birch tend to increase as recruitment exceeds mortality, except at stem counts above 1600. 


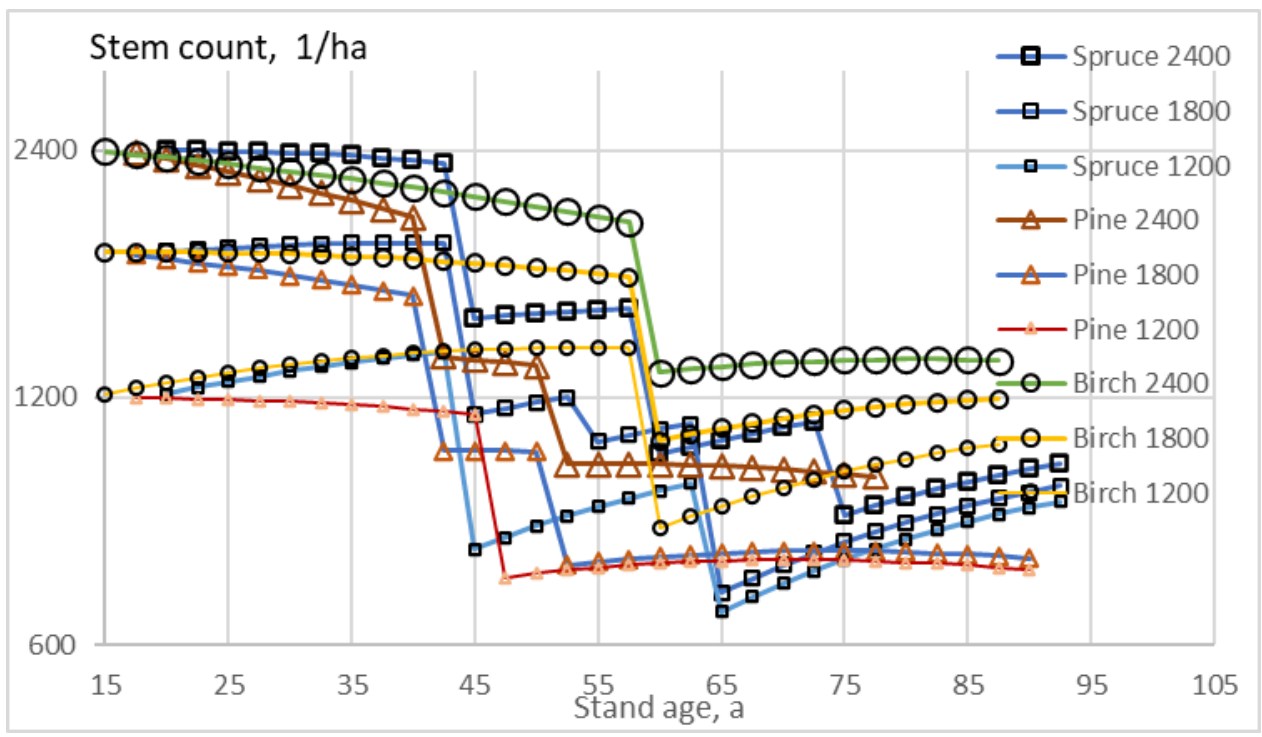

Fig. 2. Evolving stem counts for three tree species and three initial stem counts, as a function of stand age.

Development of total commercial volume per hectare, as well as the volume of sawlogs or plywood logs on for three initial stem counts, as a function of stand age for the three tree species and three initial stem counts is shown in Figs. 3a, 3b, and 3c. It is found that thinnings always remove almost all spruce sawlogs and birch plywood logs (Figs. $3 b$ and 3c). Series of two thinnings yielded only slightly inferior results for birch. In such a case, the amount of plywood logs harvested in the first thinning (Fig. 3c) was small. Despite this, it was essential to thin from above to the size of $188 \mathrm{~mm}$. This obviously is not only due to the recovery of sawlogs and plywood logs, but also due to the lower harvesting expense of large trees.

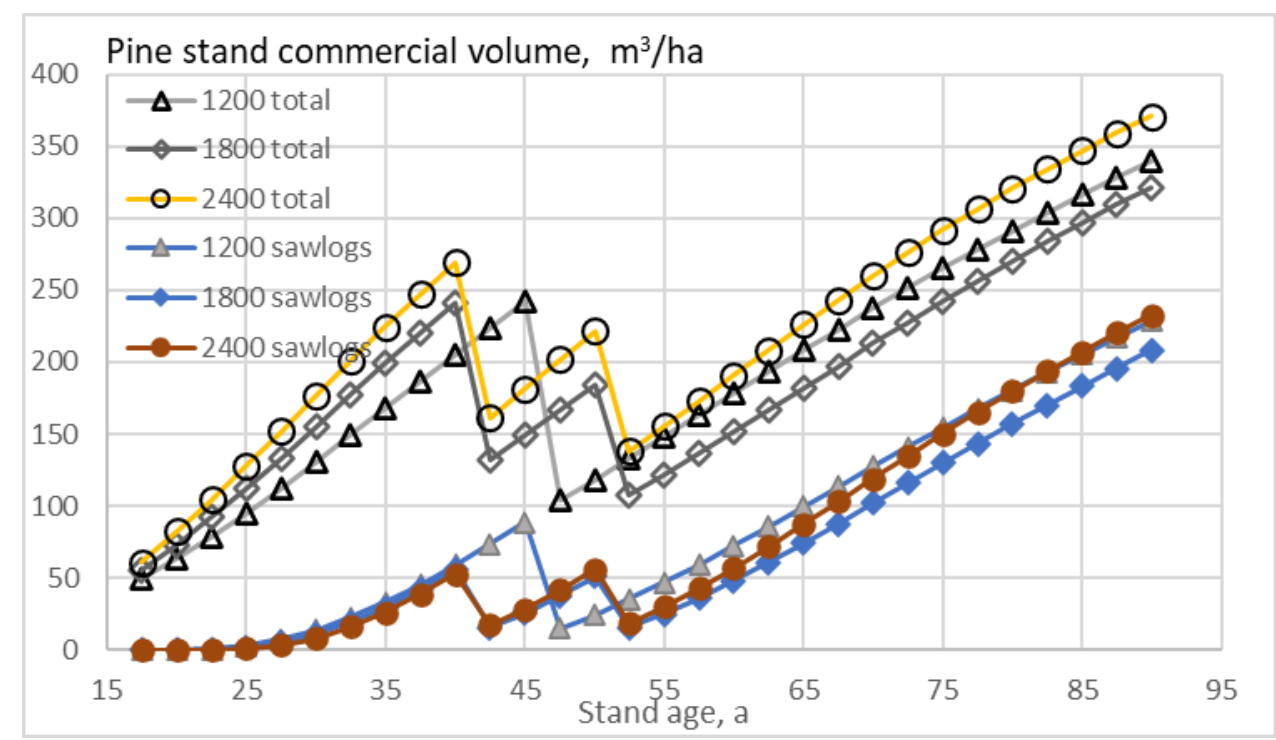


Fig. 3a. Total commercial volume, as well as the volume of sawlogs on pine stands for three initial stem counts, as a function of stand age.

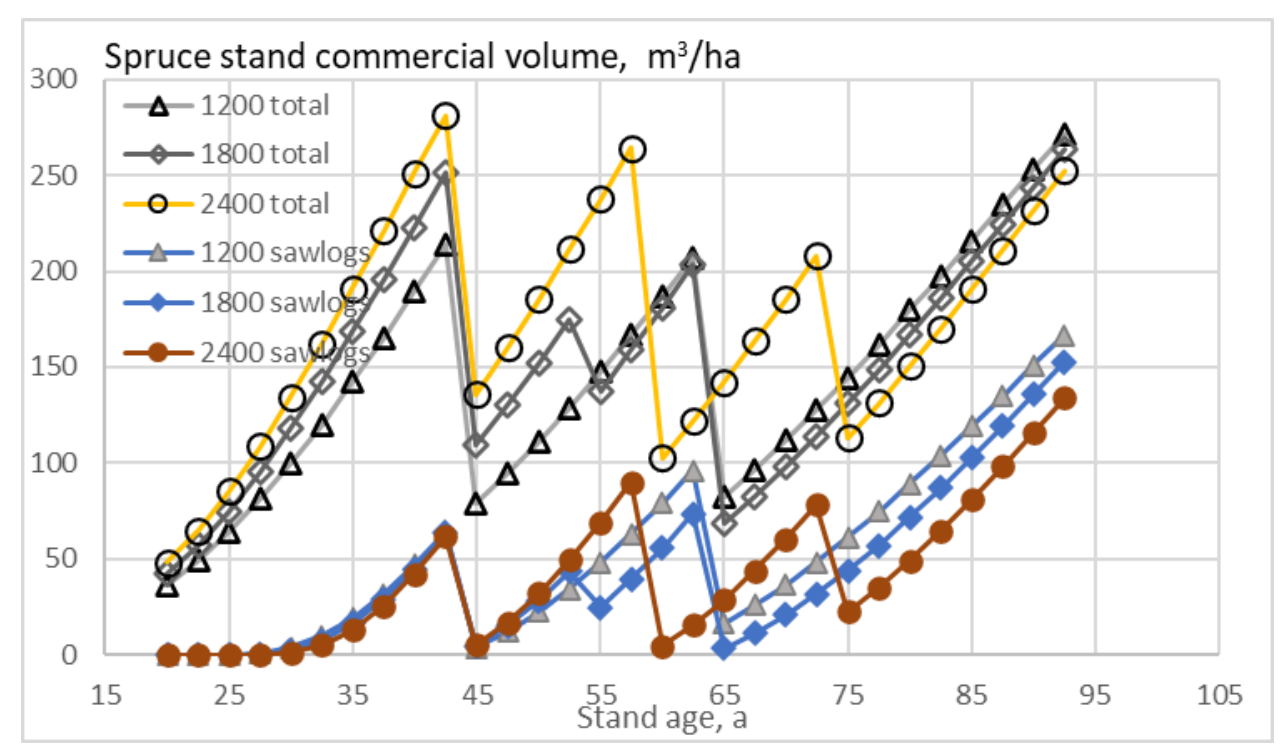

Fig. 3b. Total commercial volume, as well as the volume of sawlogs on spruce stands for three initial stem counts, as a function of stand age.

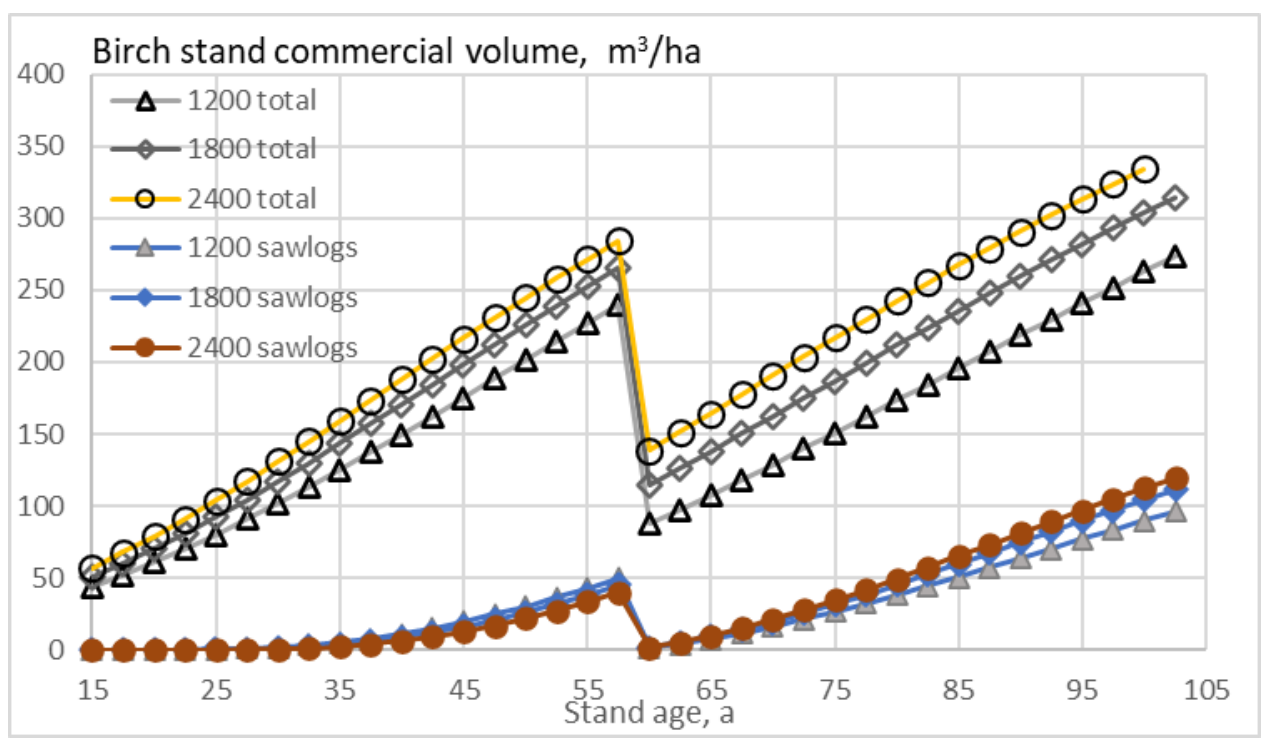

Fig.3c. Total commercial volume, as well as the volume of plywood logs on birch stands for three initial stem counts, as a function of stand age.

Fig. 4 shows the expected (average) value of commercial stand volume as a function of rotation age, for three different tree species and three initial stem counts. It is found that the timber stock is a strong function of the initial stem count. In the case of pine stands, the expected values of stand volumes corresponding to the maximum capital return rate are 121, 128, and 
$143 \mathrm{~m}^{3} / \mathrm{ha}$. The corresponding numbers for spruce stands are 115,121 , and $139 \mathrm{~m}^{3} / \mathrm{ha}$, and for birch stands 136,156 . and $171 \mathrm{~m}^{3} / \mathrm{ha}$.

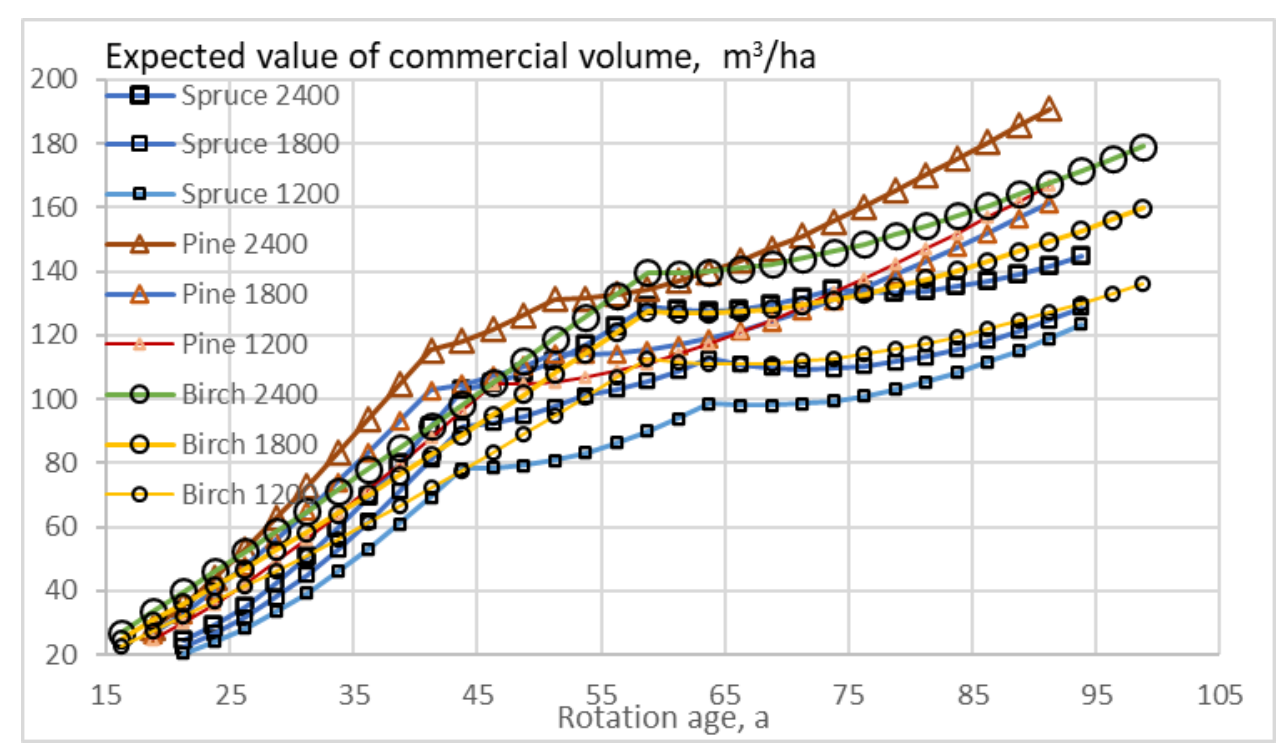

Fig. 4. Accumulated expected value of commercial volume for three tree species and three initial stem counts, as a function of rotation age.

\section{Discussion}

Maybe the most remarkable observation in the Results are the peculiar features of birch stands. The optimal rotation times are longer, and timber stockings higher, in comparison to conifers. It also is worth noting that the achievable capital return rate is much lower, less than half of that achievable for Norway spruce.

There are four obvious reasons for the bad performance of birch stands. First, after the initial development, the growth rate given by the growth model [16] is the lowest (Figs. 3a, 3b, 3c.). Secondly, the proportion of plywood logs in trunks is less than the corresponding proportions of coniferous sawlogs [23]. Thirdly, the roadside value of plywood logs is smaller than coniferous sawlogs [25,26]. Fourthly, harvesting expenses are greater than those of conifers $[27,26]$.

How do the four differences render a greater timber stocking, as well as a longer rotation time? As the capitalization due to bare land value and regeneration expenses does not differ, but the value of the standing timber per cubic meter is lower, value growth and capital return rate can 
be increased by increasing commercial stand volume. It is worth noting that stand capitalizations are not higher on birch stands.

The applied growth model does not contain any synergy between tree species [16]. In reality, some synergy exists, as broad-leaved litter improves soil $[33,34]$. It also is likely that a mixedspecies stand is less vulnerable to physical and biological threats [35,36,37]. Another particular feature of the growth model is that it retains single-species stands as such. In the case of mixedspecies stands, the species distribution evolves along with time [16].

The growth model [16] yields somewhat conservative growth estimates for conifers, in relation to inventory data regarding the Southern half of Finland [38]. However, in the case of birch, the growth estimates appear to be remarkably conservative [16,38,20,21]. A possible reason is an eventual discrepancy in tree species. Silver birch (Betula pendula) is a rather productive tree species, unlike white birch (Betula pubescens) [20,21]. It is suspected that the calibration of the growth model has mostly contained the latter.

In order to clarify the eventual birch species discrepancy, we here attempt to describe the growth of silver birch. We apply the growth model parameters of Pinus silvestris to Betula pendula while retaining all other parameters, including recruitment, mortality, plywood log content, assortment pricing and harvesting expenses. The justification is the observed similarity in growth characteristics $[17,18,19,20,21]$.

The result is shown in Fig. 5. It is shown that the birch stand rotations now are the shortest, with the exception of the highest initial stem count. The corresponding capital return rates are still lower than in the case of conifers, but clearly greater than in Fig. 1. Capital return rates 2.86\%/a, 2.94\%/a, and 2.97\%/a are achieved at rotation ages 69, 64, and 74 years for the three initial stemcounts 1200, 1800, and 2400/a. The first thinning happens at age 44, 44, and 39 years. In the case of the highest initial stem count, there is another thinning at age 54 years. The expected values of stand volumes corresponding to maximum capital return rate are 118, 144, and $158 \mathrm{~m}^{3} / \mathrm{ha}$ - considerably lower than in Fig. 4. 


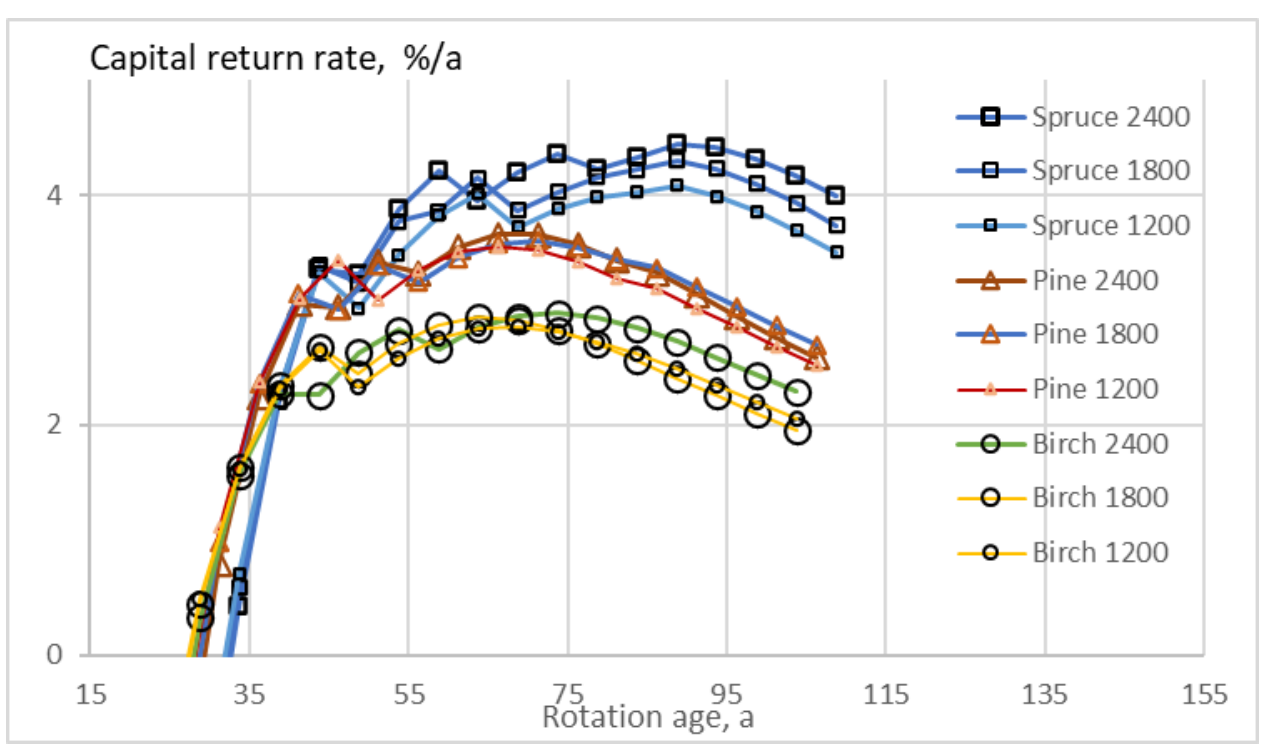

Fig. 5. Accumulated expected value of capital return rate for three tree species and three initial stem counts, as a function of rotation age. However, Pinus silvestris growth parameters have been applied for birch species.

Above, thinnings from above have been applied. Also, proportional thinnings have been attempted, but never applied because of their impairing financial effect. In all cases examined, it is better not to thin at all, in comparison to proportional thinning. On the other hand, thinnings from above only may result in the most vigorous trees removed.

Here, forest growth and yield without any thinning are investigated as an alternative to thinning from above. The result, comparable to Fig. 5, is shown in Fig. 6. Optimal rotations are much shorter, 52 years for pine, 54 years for spruce, and 49 years for birch. The capital return rates become 3.50\%/a, 3.52\%/a, and 3.44\%/a, for pine, 3.99\%/a, 4.04\%/a, and 3.99\%/a, for spruce, and $2.77 \% / \mathrm{a}, 2.77 \% / \mathrm{a}$, and $2.69 \% / \mathrm{a}$, for birch. It is worth noting that in the absence of commercial thinning, the greatest initial stem count yields the lowest capital return rate for any of the tree species. 


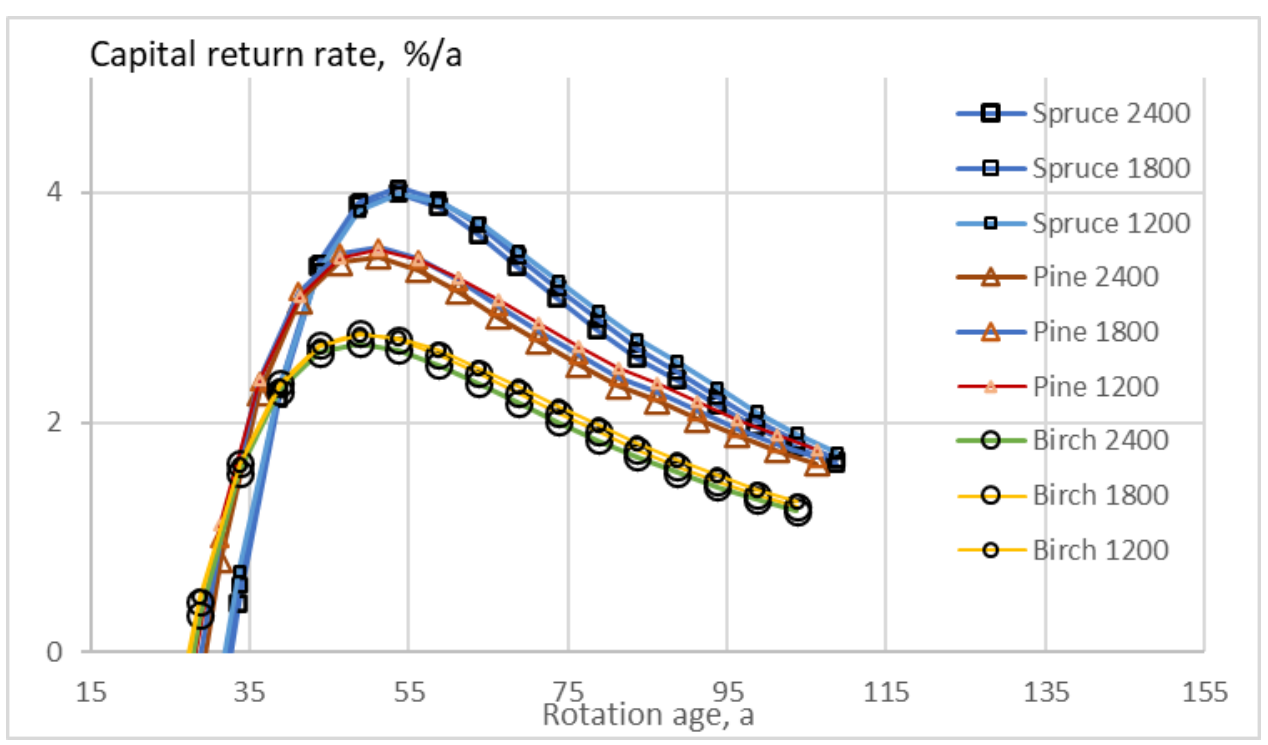

Fig. 6. Accumulated expected value of capital return rate for three tree species and three initial stem counts, as a function of rotation age, without any commercial thinning. Pinus silvestris growth parameters have been applied for birch species.

The expected value of commercial volume in the absence of any thinning is shown in Fig. 7. The expected volume values corresponding to the financially optimal rotation age are 122,142 , and $158 \mathrm{~m}^{3} /$ ha for pine, 117,136 , and $152 \mathrm{~m}^{3} /$ ha for spruce, and 126,145 , and $160 \mathrm{~m}^{3} / \mathrm{ha}$ for birch. These values are larger than those achieved by optimizing capital return rate with thinnings, especially in the case of conifers, even if the greatest difference in the average stand volume is due to the applied initial stem count. 


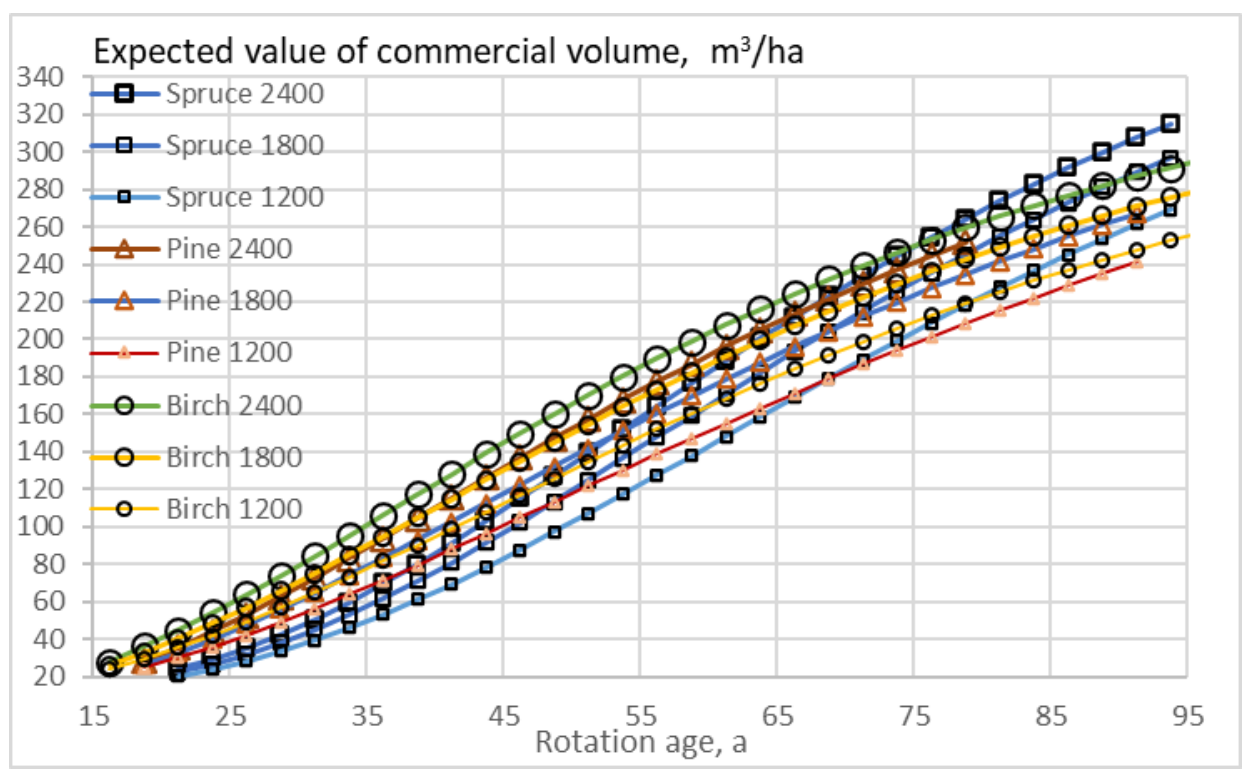

Fig. 7. Accumulated expected value of commercial volume for three tree species and three initial stem counts, as a function of rotation age, without any commercial thinning. Pinus silvestris growth parameters have been applied for birch species.

As an investment, boreal forestry does not appear very attractive, according to Figs. 1, 5, and 6. One possibility to increase the capital return rate might be to reduce the regeneration expense. The regeneration expenses above were based on excavator mounding, along with some drainage and minor road improvements, as well as the planting of nursery-grown seedlings. It is possible to use a continuously operating mounding device, instead of an excavator. It also is possible to reduce the number of planted seedlings, and partially rely on natural regeneration. One option is to combine planting and seeding. A third possibility is the application of a combined mounding-planting device. With such measures, the regeneration expense can be reduced by $500 \mathrm{Eur} / \mathrm{ha}$, according to the present expense level in the reference area.

The effect of reduced regeneration expense on capital return rate is shown in Fig. 8. In all cases, the achievable capital return rate is more than $10 \%$ greater than in Fig. 5. In most cases, the optimal rotation is shorter, and in a few cases, the number of thinnings is reduced. In the case of pine stands of initial stem count 1200 and 1800/ha, the rotations become ten years shorter, and the capital return rate increases by $16 \%$. In the case of initial stem count 2400 , the rotation age is the same, and the capital return rate increases by $13 \%$. 
In the case of spruce stands of initial stem count 1200, 1800, and 2400/ha, the rotations become 25,20 , and 15 years shorter, and the capital return rate increases by $14 \%, 13 \%$, and $10 \%$. In the case of birch stands of initial stem count 1200, 1800, and 2400/ha, the rotations become 10, 5 and 5 years shorter, and the capital return rate increases by $18 \%, 16 \%$, and $14 \%$.

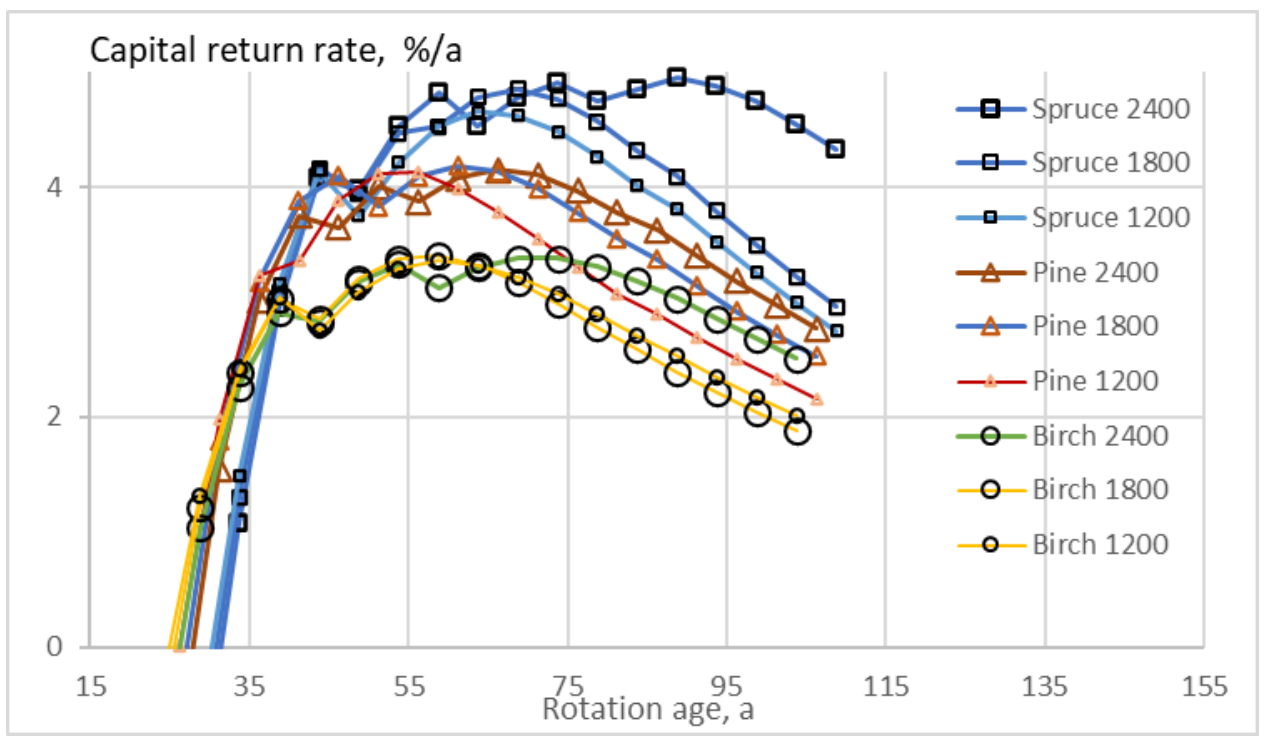

Fig. 8. Accumulated expected value of capital return rate for three tree species and three initial stem counts, as a function of rotation age. Regeneration expense has been reduced by 500 Eur/ha, in comparison to Fig. 1. Pinus silvestris growth parameters have been applied for birch species.

Again, proportional thinnings are not applicable. A feasible alternative to thinnings from above is to apply no commercial thinning. The capital return rate without commercial thinning, comparable to Fig. 6 but with reduced regeneration expense, is shown in Fig. 9.

For all the three pine stands, the rotations are five years shorter in Fig. 9 than in Fig. 6. The capital return rates are $17 \%, 16 \%$, and $16 \%$ greater. The rotation age is the same for spruce stands of 1200 and 1800/ha initial stem count, and five years shorter for 2400/ha. The capital return rates are 15\%,14\%, and 13\% greater in Fig. 9. For all three cases of birch stands, the rotation ages are the same in Figs. 6 and 9. The capital return rates are 20\%, 18\%, and 18\% greater. 


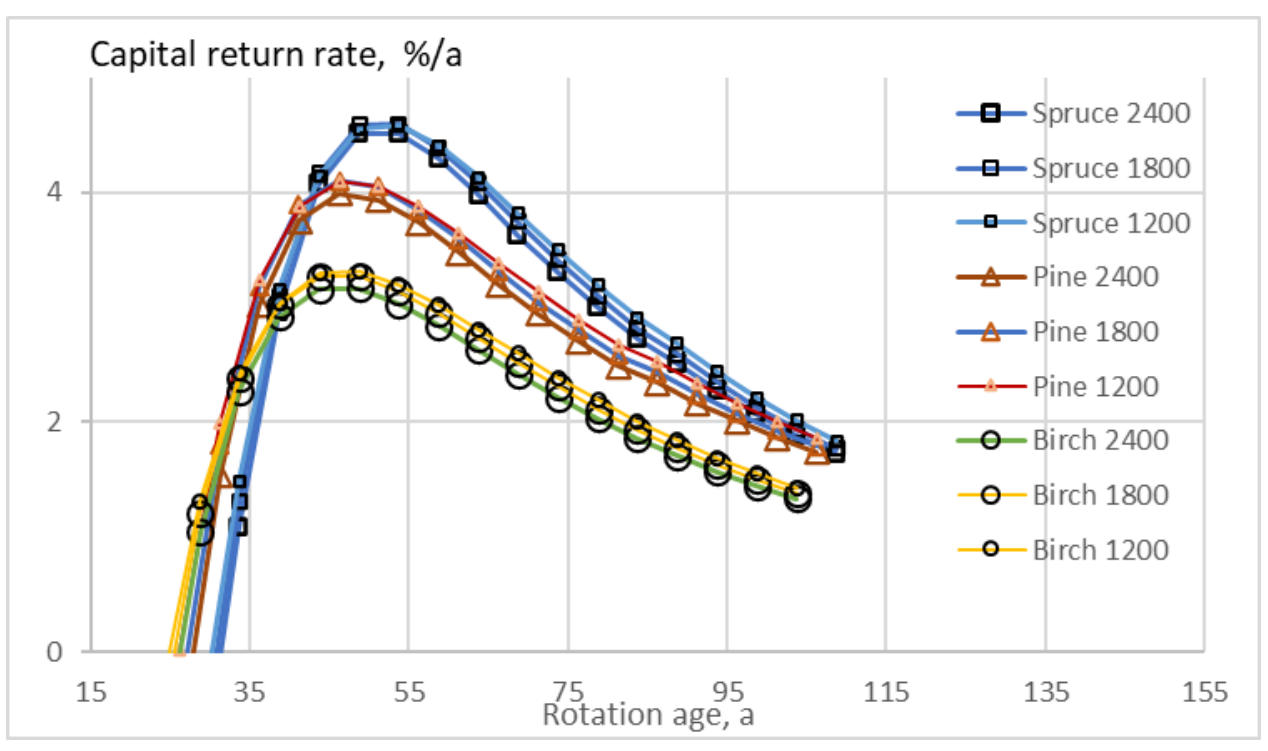

Fig. 9. Accumulated expected value of capital return rate for three tree species and three initial stem counts, without any commercial thinning. Regeneration expense has been reduced by 500 Eur/ha, in comparison to Fig. 6. Pinus silvestris growth parameters have been applied for birch species.

It is worth noting that no restrictions were applied in the design of thinning procedures. Consequently, the applied thinnings reflect those suitable from the viewpoint of maximizing capital return rate. Fig. 10 shows the combination of stem count and commercial volume where thinnings appearing in Fig. 8 are triggered. It is found that with the exception of the pine stand with the lowest initial stem count, first thinnings are triggered at stand volumes in excess of $200 \mathrm{~m}^{3} /$ ha. Further thinnings are triggered at lower stem counts and generally also lower stand volumes than the first thinning. 


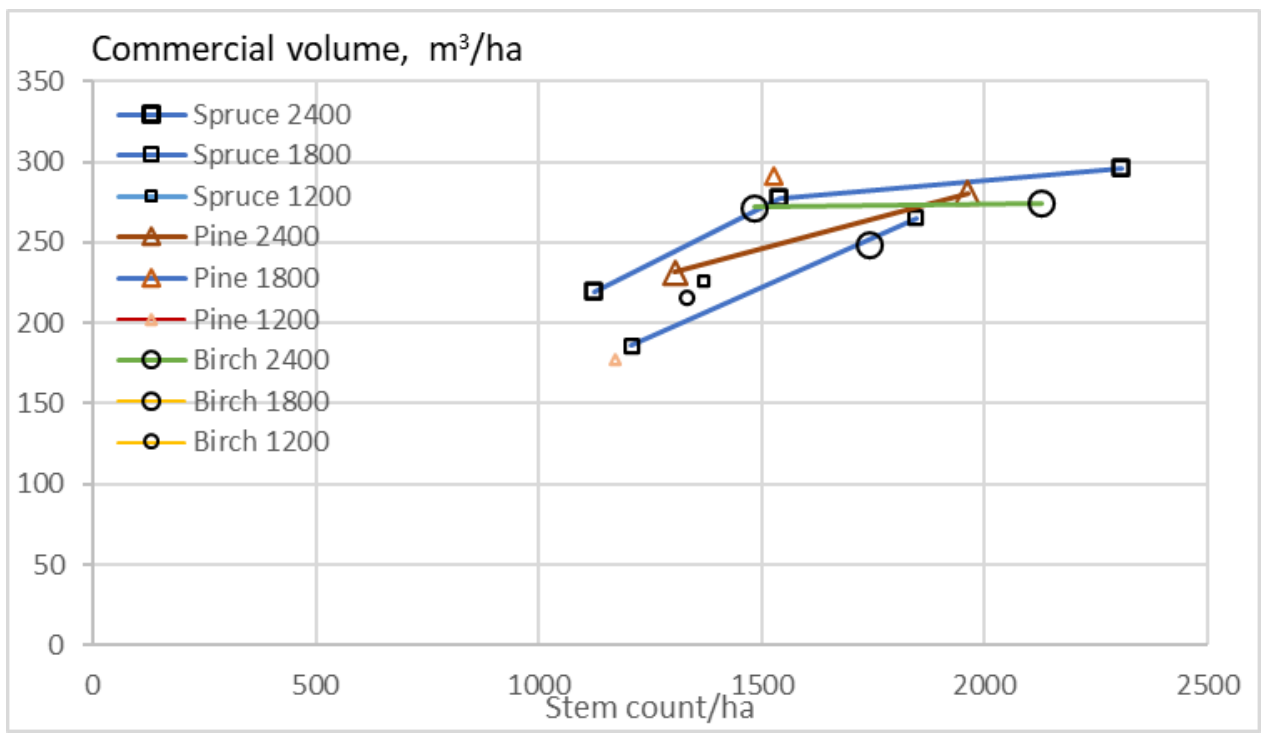

Fig. 10. Commercial volume and stem count where thinnings are triggered. Observations are in accordance with Fig. 8. Thinnings implemented on the same stand are connected.

Fig. 11 shows the relationship of removed stem count and removed commercial volume in thinning, corresponding to procedures appearing in Fig. 8. We find that the arithmetic average commercial volume of harvested trees is never less than 200 liters. In the case of multiple thinnings, the first thinning always harvests the greatest stem count. All thinnings extract more than 100 cubic meters of commercial timber, except the second thinning in spruce stands of initial stem count 1800/ha and the only thinning of pine stands of initial stem count 1200/ha.

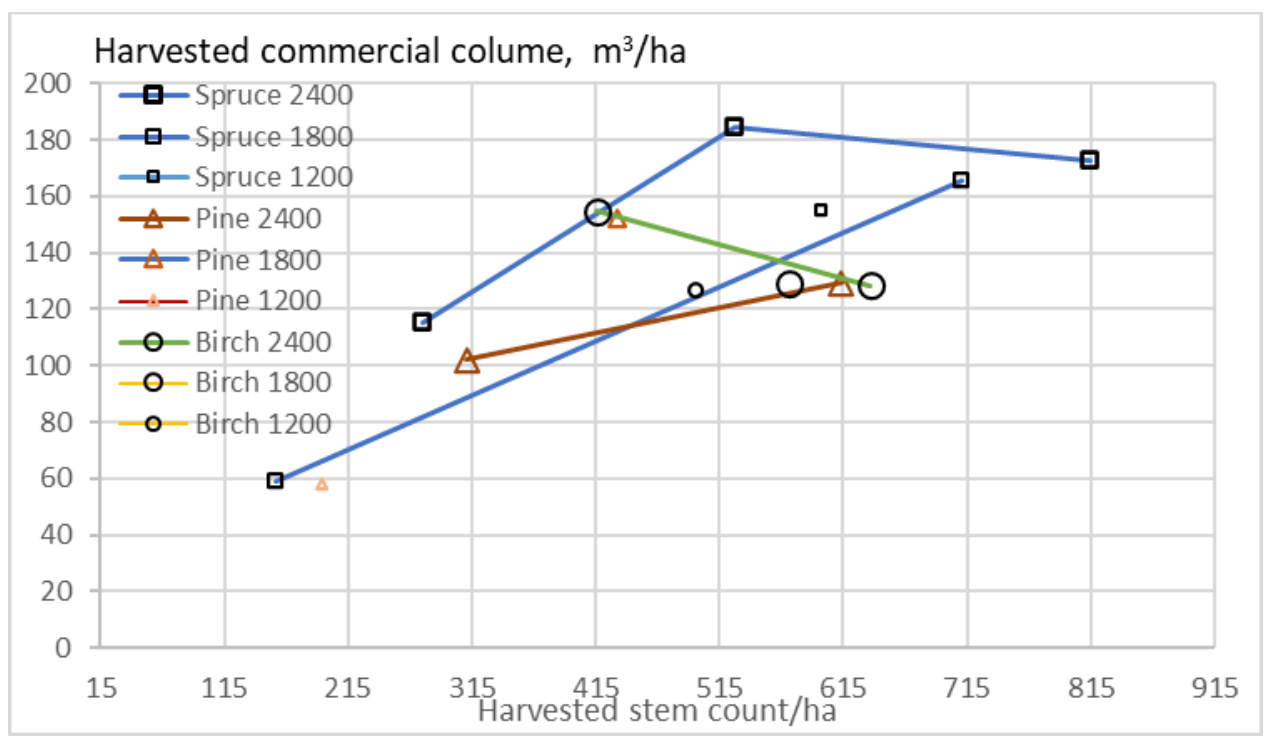

Fig. 11. Harvested commercial volume as a function of harvested stem count in thinnings. Observations are in accordance with Fig. 8. Thinnings implemented on the same stand are connected. 
After thinnings, what is left for clearcutting? That is shown in Fig. 12. In all cases, the commercial volume harvested in clearcutting is between $200 \mathrm{~m}^{3} / \mathrm{ha}$ and $300 \mathrm{~m}^{3} / \mathrm{ha}$. The sawlog content of pine stands is the greatest with the smallest initial stem count, $46 \%$. The sawlog contents with the larger initial stem counts are $39 \%$ and $41 \%$.

The sawlog contents of spruce stands are $48 \%, 47 \%$, and $48 \%$. The plywood log contents of the birch stands are $28 \%, 27 \%$, and $23 \%$.

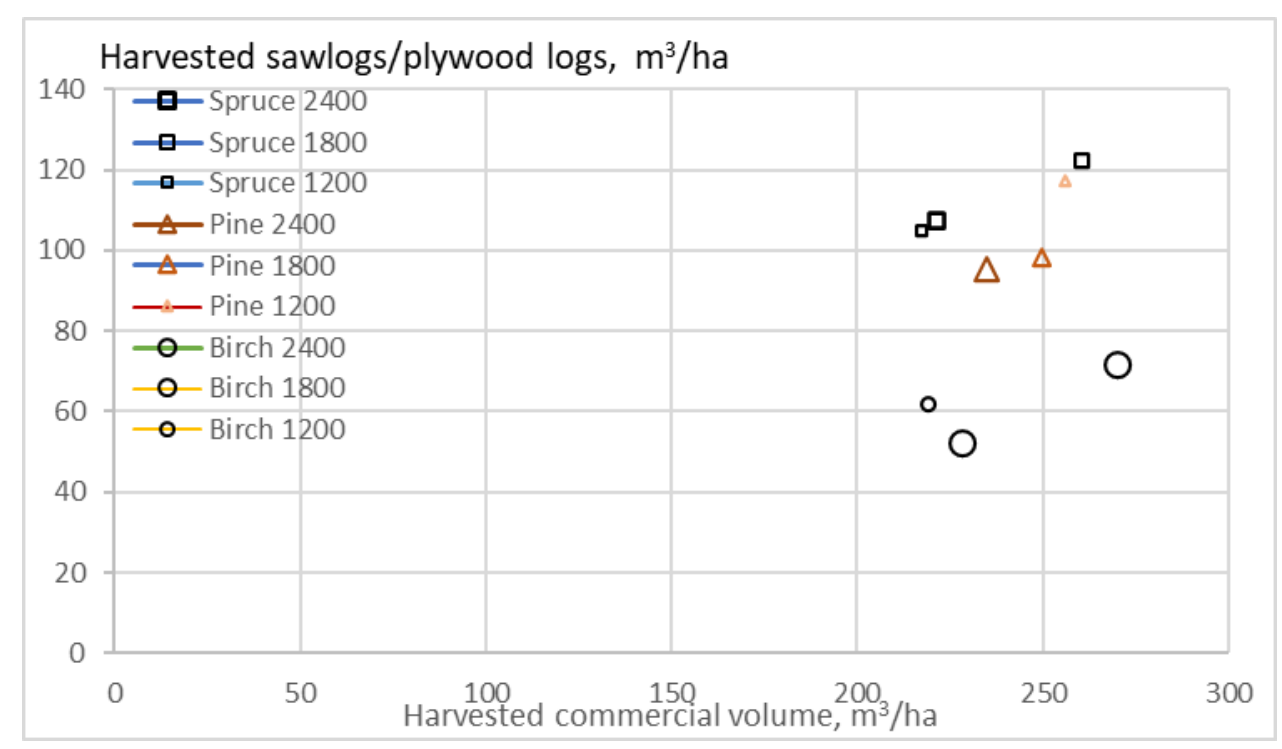

Fig. 12. Harvested sawlog or plywood log content as a function of harvested commercial volume in clearcutting. Observations are in accordance with Fig. 8.

Fig. 13 shows the volumetric yield of sawlogs/plywood $\operatorname{logs}$ as a function of the yield of commercial volume in clearcutting, without any commercial thinning. In comparison to Fig. 12 , the volumetric yield is greater than with thinnings, but the proportion of sawlogs/plywood $\operatorname{logs}$ is smaller. The commercial volume harvested is between 250 and $370 \mathrm{~m}^{3} / \mathrm{ha}$. The proportion of sawlogs is $38 \%, 33 \%$, and $29 \%$ for pine, and $48 \%$, $43 \%$, and $33 \%$ for spruce. The proportion of birch plywood logs is $28 \%, 27 \%$, and $23 \%$. 


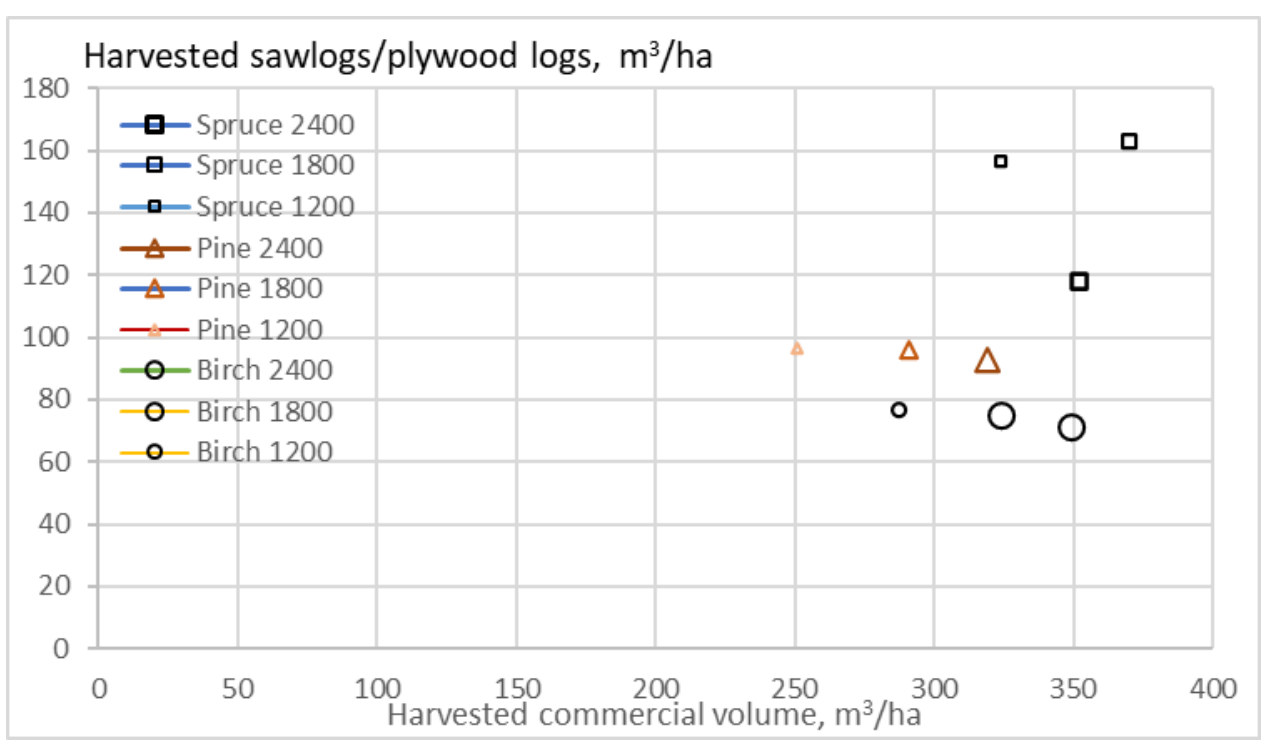

Fig. 13. Harvested sawlog or plywood log content as a function of harvested commercial volume in clearcutting, in the absence of any commercial thinning. Observations are in accordance with Fig. 9.

The general theory of risk proposes long-term commitments contain more uncertainty than short-term commitments [39,40,41]. Within forestry, "duration risk" not only refers to interest rate risk, but to a variety of uncertain or unknown changes along with time. Correspondingly, small differences in the expected value of capital return rate in Figs. 1, 5, and 8 propose that short rotation times possibly should be used. The absence of thinnings in Figs. 6 and 8 further reduce commitment times. However, neglecting thinnings also removes thinning revenues.

The size scale of the operation of any business agent is finite. Large investments involve greater concentration risk than smaller, distributed investments [39,40,41]. The difference in the expected value of capital return rate between different kinds of regeneration procedures being small (Figs. 1, 5, 6, 8, and 9), inexpensive regeneration practices possibly should be favored, including low planted stem counts per hectare. The situation would change if a significant carbon storage compensation would exist [10,13, Fig. 4].

There is one factor possibly contradicting the application of short rotation times and low stem counts. Fig. 5 indicates that extending rotation time tends to increase the expected value of trunk volume, as does increased stem count. This naturally contributes to the storage of carbon in forestry. The effect of stem count on the storage is greater than that of the rotation age (Fig. 5). If a reasonable carbon rent is applied $[10,13]$, it justifies higher stem counts and longer 
rotation times. It is further worth noting that neglecting thinnings increases carbon storage (Figs. 4 and 7).

The main difference in the present results, in comparison to common practices applied in the reference area, is the size of trees harvested in thinnings. The origin of the average volume of harvested trees always exceeding 200 liters obviously is in the harvesting expense function $[27,26]$. Thinnings naturally can be applied on smaller trees if the expenses can be made reasonable. However, agreements with low harvesting prices on small trees may not be sustainable, provided the harvesting productivity function is unbiased.

It is here worth noting that individual trees were above characterized by two parameters: tree species and size. In real life, the characteristics of any tree may depend on its age, and position within the population, along with a variety of other factors. The other contributors form a complex field - the author is not able to present any comprehensive description of them at the present time.

In this study, fertile and semi-fertile boreal forests on mineral soil were discussed. That type of forest dominates forest production in the reference area with an area proportion of 59\% [38]. Any of the investigated three tree species are applicable in the investigated type of forest. Any significant deviation from such forest type would change things. Significantly lower fertility would exclude the tree species of Norway spruce and Silver birch. Planting of seedlings would be replaced by seeding of Scots pine. On the other hand, peatlands, with the exception of the most fertile, might fall into the regime of natural regeneration, or possibly continuous-cover forestry. Such circumstances are out of the scope of this study.

In coarse terms, the results of this study can be compared with national statistics of the reference area [38]. The growth rates given by the growth model [16], calibrated in Norway, appear somewhat conservative in the Southern half of Finland [38]. One consequence is that the capital return rates reported in this paper are not higher than typical values indicated by national statistics, even if they have been optimized in this paper. It is further worth noting that the average profitability of forestry is available from one center of statistics [38], whereas the market value of forest estates has to be indirectly deduced from another source [42]. 


\section{Conclusions}

Regeneration expenses were amortized first at the end of any rotation. Consequently, capitalizations became greater and rotations longer than in recent studies. The capital return rate is a weak function of initial stem count but differs by tree species. The initial stem count strongly contributes to biomass stored in trees. The most promising way of increasing the capital return rate is the reduction of regeneration expenses. Thinnings are triggered by stand volumes of at least $200 \mathrm{~m}^{3} / \mathrm{ha}$. The average commercial trunk volume of trees removed in thinnings always exceeds 200 liters. Risk aversion theory proposes short rotations and low stem count in seedling planting unless carbon storage compensation exists.

\section{Acknowledgement}

This work was partially funded by Niemi Foundation.

\section{References}

1. Gustavsson, L.; Haus, S.; Lundblad, M.; Lundström, A.; Ortiz, C.A.; Sathre, R.; Truong, N.; Wikberg, P.-E. Climate change effects of forestry and substitution of carbon-intensive materials and fossil fuels. Renew. Sustain. Energy Rev. 2017, 67, 612-624, doi:10.1016/j.rser.2016.09.056.

2. Van Kooten, G.C.; Bogle, T.N.; De Vries, F.P. Forest Carbon Offsets Revisited: Shedding Light on Darkwoods. For. Sci. 2015, 61, 370-380, doi:10.5849/forsci.13-183.

3. Van Kooten, G.C.; Johnston, C.M.T. The Economics of Forest Carbon Offsets. Annu. Rev. Resour. Econ. 2016, 8, 227-246, doi:10.1146/annurev-resource-100815-095548.

4. Pukkala, T. Carbon forestry is surprising. For. Ecosyst. 2018, 5, doi:10.1186/s40663-0180131-5.

5. Seppälä, J.; Heinonen, T.; Pukkala, T.; Kilpeläinen, A.; Mattila, T.; Myllyviita, T.; Asikainen, A.; Peltola, H. Effect of increased wood harvesting and utilization on required greenhouse gas displacement factors of wood-based products and fuels. J. Environ. Manag. 2019, 247, 580-587, doi:10.1016/j.jenvman.2019.06.031.

6. Kilkki, P.; Väisänen, U. Determination of the optimum cutting policy for the forest stand by means of dynamic programming. Acta For. Fenn. 1969, 102, 1-23, doi:10.14214/aff.7613. 
7. Kärenlampi, P.P. Harvesting Design by Capital Return. Forests 2019, 10, 283, doi:10.3390/f10030283.

8. Kärenlampi, P.P. The effect of capitalization on financial return in periodic growth. Heliyon 2019, 5, e02728, doi:10.1016/j.heliyon.2019.e02728.

9. Kärenlampi, P.P. Estate-Level Economics of Carbon Storage and Sequestration. Forests 2020, 11(6), 643; https://doi.org/10.3390/f11060643.

10. Lintunen, J.; Laturi, J.; Uusivuori, J. How should a forest carbon rent policy be implemented? For. Policy Econ. 2016, 69, 31-39, doi:10.1016/j.forpol.2016.04.005.

11. Pukkala, T. At what carbon price forest cutting should stop. J. For. Res. 2020, 31, 713-727, doi:10.1007/s11676-020-01101-1.

12. Kärenlampi, P.P. Stationary Forestry with Human Interference. Sustainability 2018, 10, 3662, doi:10.3390/su10103662.

13. Kärenlampi, P.P. The Effect of Empirical Log Yield Observations on Carbon Storage Economics. Forests 2020, 11, 1312.

14. Kärenlampi, P.P. Diversity of Carbon Storage Economics in Fertile Boreal Spruce (Picea Abies) Estates. Sustainability 2021, 13, 560. https://www.mdpi.com/2071-1050/13/2/560

15. Leslie, A.J. A review of the concept of the normal forest. Aust. For. 1966, 30, 139-147, doi:10.1080/00049158.1966.10675407.

16. Bollandsås, O.M.; Buongiorno, J.; Gobakken, T. Predicting the growth of stands of trees of mixed species and size: A matrix model for Norway. Scand. J. For. Res. 2008, 23, 167-178, doi:10.1080/02827580801995315.

17. Vuokila, Y., Männyn kasvusta ja sen vaihteluista harventaen käsitellyissä ja luonnontilaisissa metsiköissä. 38 s., kuv. On growth and its variations in thinned and unthinned Scots pine stands. Comm. Inst. For. Fenn. 52.7. (1960).

18. Vuokila, Y.; Väliaho, H., Viljeltyjen havumetsiköiden kasvatusmallit. Growth and yield models for conifer cultures in Finland. Comm. Inst. For. Fenn. 99.2. (1980). 271 p.

19. Vuokila, Y., Etelä-Suomen hoidettujen kuusikoiden kehityksestä. Viljeltyjen havumetsiköiden kasvatusmallit. On the development of managed spruce stands in Southern Finland. Comm. Inst. For. Fenn. 48.1. (1956). 138 p.

20. Raulo, J. Development of dominant trees in Betu-la pendula Roth and Betula pubescens Ehrh. planta-tions. Seloste: Viljeltyjen raudus- ja hieskoivikoidenvaltapuiden kehitys. Communicationes Instituti Forestalis Fenniae 90, 1977, 4. 
21. Oikarinen, M. Etelä-Suomen viljeltyjen raudus-koivikoiden kasvatusmallit. Suumary: Growth andyield models for silver birch (Betula pendula) plantations in southern Finland. Communicationes InstitutiForestalis Fenniae 113, 1983.

22. Kärenlampi. P. P. Empirical observations of the yield of logs from trees of the boreal region. Submitted to Baltic Forestry, Feb. 4., 2021.

23. Mehtätalo, L. Valtakunnalliset puukohtaiset tukkivähennysmallit männylle, kuuselle, koivuille ja haavalle. Metsätieteen aikakauskirja 4/2002, 575-591.

24. Laasasenaho, J. Taper curve and volume functions for pine, spruce and birch. Comm. Inst. For. Fenn. 108, 1982.

25. Parkatti, V.-P.; Assmuth, A.; Rämö, J.; Tahvonen, O. Economics of boreal conifer species in continuous cover and rotation forestry. For. Policy Econ. 2019, 100, 55-67, doi:10.1016/j.forpol.2018.11.003.

26. Parkatti, V-P.; Tahvonen, O. Optimizing continuous cover and rotation forestry in mixedspecies boreal forests. Canadian Journal of Forest Research, 50(11), 2020, 1138-1151. https://doi.org/10.1139/cjfr-2020-0056

27. Nurminen, T.; Korpunen, H.; Uusitalo, J. Time consuming analysis of the mechanized cutto-length harvesting system. Silva Fenn. 2006, 40, 335-363.

28. Pressler, M.R. Aus der Holzzuwachlehre (zweiter Artikel). Allgemeine Forst und Jagd Zeitung, 1860, 36, 173-191. Translated by W. Löwenstein and J.R. Wirkner as "For the comprehension of net revenue silviculture and the management objectives derived thereof'. J. Forest Econ. 1995, 1, 45-87.

29. Kärenlampi, P.P. State-space approach to capital return in nonlinear growth processes. Agric. Finance Rev. 2019, 79, 508-518, doi:10.1108/afr-07-2018-0055.

30. Kärenlampi, P.P. Wealth accumulation in rotation forestry-Failure of the net present value optimization? PLoS ONE 2019, 14, e0222918, doi:10.1371/journal.pone.0222918.

31. Speidel, G. Forstliche Betreibswirtschaftslehre, 2nd ed.; Verlag Paul Parey: Hamburg, Germany, 1967, 226p. (In German)

32. Speidel, G. Planung in Forstbetrieb, 2nd ed.; Verlag Paul Parey: Hamburg, Germany, 1972; 270p. (In German)

33. Woś B, Pietrzykowski M. Simulation of Birch and Pine Litter Influence on Early Stage of Reclaimed Soil Formation Process under Controlled Conditions. J Environ Qual. 2015 Jul;44(4):1091-8. doi: 10.2134/jeq2014.07.0315. PMID: 26437090.

34. Augusto, L.; De Schrijver, A.; Vesterdal, L.; Smolander, A.; Prescott, C.; Ranger, J. Influences of evergreen gymnosperm and deciduous angiosperm tree species on the functioning 
of temperate and boreal forests. Biol Rev Camb Philos Soc. 2015 May;90(2):444-66. doi: 10.1111/brv.12119. Epub 2014 Jun 11. PMID: 24916992.

35. Kohnle, U. (2015): Spruce and climate change - what is to be done? www.waldwissen.net 36. Seidl, R.; Thom, D.; Kautz, M.; Martin-Benito, D.; Peltoniemi, M.; Vacchiano, G.; Wild, J.; Ascoli, D.; Petr, M.; Honkaniemi, J.; Lexer, M.J.; Trotsiuk, V.; Mairota, P.; Svoboda, M.; Fabrika, M.; Nagel T.A,; \& Reyer, C.P.O. Forest disturbances under climate change. Nature Climate Change volume 7, 2017, 395-402.

37. Felton, A.; Petersson, L.; Nilsson, O.; Witzell, J.; Cleary, M.; Felton, .M.; Björkman, C.; Sang, Å.O.; Jonsell, M.; Holmström, E.; Nilsson, U.; Rönnberg, J.; Kalén, C.; Lindbladh, M. The tree species matters: Biodiversity and ecosystem service implications of replacing Scots pine production stands with Norway spruce. Ambio 49, 2020, 1035-1049. https://doi.org/10.1007/s13280-019-01259-X

\section{8. https://www.luke.fi/avoin-tieto/tilastopalvelu/}

39. Bouchaud J.-P.; Potters M. Th'eorie des Risques Financiers (Saclay: Al'ea) 1997 (Engl. transl. 2000) Theory of Financial Risks (Cambridge: Cambridge University Press))

http://web.math.ku.dk/ rolf/Klaus/bouchaud-book.ps.pdf

40. Brealey, R.A.; Myers, S.C.; Allen, F. (2011), Principles of Corporate Finance (Tenth ed. 2011), New York, NY: McGraw-Hill Irwin.

41. Fabozzi, F.J. Capital Markets: Institutions, Instruments, and Risk Management. MIT Press 2015. ISBN 978-0-262-33159-3.

42. https://khr.maanmittauslaitos.fi/tilastopalvelu/rest/API/kiinteistokauppojentilastopalvelu.html\#t443g4_x_2020_x_Makunta 